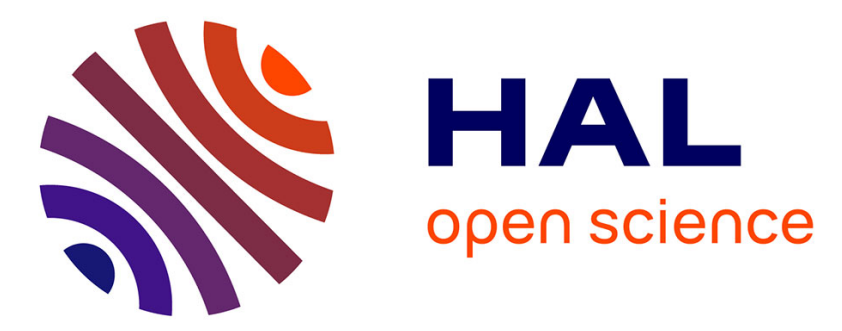

\title{
Syn-tectonic sedimentary evolution of the Miocene Çatallar Basin, southwestern Turkey
}

Erdal Kosun, André Poisson, A. Ciner, Roland Wernli, Olivier Monod

\section{To cite this version:}

Erdal Kosun, André Poisson, A. Ciner, Roland Wernli, Olivier Monod. Syn-tectonic sedimentary evolution of the Miocene Çatallar Basin, southwestern Turkey. Journal of Southeast Asian earth sciences, 2009, 34 (3), pp.466-479. 10.1016/j.jseaes.2008.07.005 . insu-00371833

\section{HAL Id: insu-00371833 \\ https://hal-insu.archives-ouvertes.fr/insu-00371833}

Submitted on 1 Apr 2009

HAL is a multi-disciplinary open access archive for the deposit and dissemination of scientific research documents, whether they are published or not. The documents may come from teaching and research institutions in France or abroad, or from public or private research centers.
L'archive ouverte pluridisciplinaire HAL, est destinée au dépôt et à la diffusion de documents scientifiques de niveau recherche, publiés ou non, émanant des établissements d'enseignement et de recherche français ou étrangers, des laboratoires publics ou privés. 


\title{
Syn-tectonic sedimentary evolution of the Miocene Çatallar Basin, southwestern Turkey
}

\author{
Erdal Kosun a , André Poisson ${ }^{b}$, Attila Çiner ${ }^{c}$, Roland Wernli ${ }^{\mathrm{d}}$ and Olivier Monod \\ ${ }^{a}$ Akdeniz University, Department of Geological Engineering, Merkez Kampus, 07000 \\ Antalya, Turkey \\ ${ }^{\mathrm{b}}$ Université Paris-Sud, Sciences de la Terre, Batiment 504, 91405 Orsay Cedex, France \\ ${ }^{\mathrm{c}}$ Hacettepe University, Department of Geological Engineering, Beytepe, 06800 Ankara, \\ Turkey
}

${ }^{\mathrm{d}}$ Université de Genève, Géologie et Paléontologie, 13 rue des Maraîchers, CH-1211 Genève 4, Switzerland

${ }^{\text {e} U n i v e r s i t e ́ ~ d ' O r l e ́ a n s, ~ U n i v e r s i t e ́ ~ F r a n c ̧ o i s ~ R a b e l a i s ~-~ T o u r s, ~ C N R S / I N S U ~}$

Institut des Sciences de la Terre d'Orléans - UMR 6113

Campus Géosciences - 1A, rue de la Férollerie

45071 Orléans cedex 2 France

\begin{abstract}
The Çatallar Basin is one of the Miocene basins located in the southern part of the Bey Dağları Massif (SW Turkey). This basin has been reinvestigated and new stratigraphic and sedimentological data are now presented. The Çatallar Basin lies in paraconformity on the Bey Dağları carbonate platform of Late Cretaceous to Palaeogene age. It consists of an impersistent, shallow-marine carbonate base (Karabayır formation, Late Oligocene to Early Burdigalian) followed by an onlapping detrital sequence including the Akçay and Bağbeleni formations (Langhian to Serravallian). The Akçay formation mainly contains turbidites in which several debris-flows and olistostromes are intercalated. The lowest debris flows derive from the local carbonate platforms of Cretaceous and Palaeogene age. Higher, the debris flows and olistostromes contain large carbonate blocks deriving from nearby sources (Bey Dağlar1 platform carbonates), whereas the accompanying pebbles originate from the allochthonous ophiolitic units located farther to the north (Lycian Nappes) or to the east (Antalya Nappes). The origin of these ophiolitic detritus is a matter of debate. The new data obtained in this study favour a northern origin.
\end{abstract}

Keywords: Sedimentology; Biostratigraphy; Source of detritals; Miocene; Basin analyses; Lycian Nappes

\section{Introduction}

In southwestern Turkey, two sets of nappes are thrust over the Bey Dağları carbonate platform: the Lycian Nappes to the northwest, and the Antalya Nappes to the east ([Brunn et al., 1971], [Poisson, 1977], [Gutnic et al., 1979] and [Robertson, 2000]).

The Antalya Nappes were first emplaced during the latest Cretaceous and the Paleocene upon the southeastern margin of the Bey Dağları platform ([Poisson, 1977], [Gutnic et al., 1979] 
and [Robertson, 2000]). Although strongly debated, their origin from the southern branch of the Neotethys is generally accepted now (see discussion in [Robertson et al., 2003] and [Poisson et al., 2003b]).

The Lycian Nappes, issued from the Northern branch of the Neotethys were initially thrust southwards upon the margin of the Anatolian micro-continent during the Late Cretaceous. Subsequent southwards thrusting across the Anatolian micro-continent brought the Lycian Nappes to their present position during the Langhian (Poisson, 1977). The tectonic emplacement and the following erosion of the Lycian units were responsible for the development of a Miocene foreland basin along the thrust front (Lycian Basin, Fig. 1) (Flecker et al., 2005), but also for the deposition of finer detritals that were spread over most of the Bey Dağları platform during the same period. The final infill of these basins during the Middle to Upper Miocene provides reliable insights about the nature of the eroded rock units, and reflects the chronology of the coeval tectonic events in the region.

Presently, only the edge of the Lycian Basin is exposed along the SE front of the Lycian Nappes. Most of the basin is hidden below the nappes except for a tectonic window near Göcek, $75 \mathrm{~km}$ from the thrust front (insert in Fig. 1). The succession of the detrital formations infilling the Lycian Basin during Burdigalian and Langhian reflects the progression of the Lycian Nappes towards the Bey Dağları platform. The first deposits (Middle Burdigalian) are distal turbidites in a deep environment indicating that the front of the nappes was still far away to the north. By the end of the Burdigalian and early in the Langhian, coarser clastics (sandstones and micro-conglomerates) are deposited in a shallow-marine environment. Last, fluvio-marine and deltaic coarse conglomerates with occasional coral reefs (Middle Langhian) complete the detrital sequence of the Lycian Basin, just before the final emplacement of the nappes. A regional emersion of the Lycian units and of large parts of the Bey Dağları during the Late Langhian is indicated by the arrival of polymictic clastics into the outer Miocene basins located further south. Among these, lies the Kasaba Basin ([Poisson, 1977] and [Hayward, 1982]) where shallow-marine alluvial fan and fan deltas along its NW margin show that its filling immediately followed that of the Lycian Basin.

Farther away southwards, the Çatallar, Sidek and Salur Basins are smaller, partly coeval Miocene basins, situated on the Bey Dağları platform. During the Middle and Late (?) Miocene, these basins were filled with fine to coarse detritals coming from allochthonous units containing ophiolites. Owing to the position of these basins (Fig. 1 and Fig. 5) their source rocks could either be situated in the Lycian Nappes to the northwest or in the Antalya Nappes to the east. Although the Lycian origin of the ophiolitic detritals filling the Kasaba Basin is not disputed ([Poisson, 1977] and [Hayward, 1982]), the origin of the ophiolitic conglomerates present in the Çatallar and in the Salur Basins is more controversial.

On the basis of facies and biostratigraphic studies in the Çatallar Basin, Poisson and Akay (1981) suggested that the ophiolitic materials also derived from the Lycian Nappes during the Langhian, as in the neighbouring Kasaba Basin. On the opposite, Hayward and Robertson (1982), on the basis of current direction measurements, concluded that the ophiolitic pebbles both in the Çatallar Basin and in the Salur Basin derived from the Antalya units during the Early Miocene, and considered it as an evidence for a southern origin for the Antalya units.

Presently, two critical issues are thus disputed in the Çatallar and Salur Basins: the timing (Early Miocene or Middle Miocene) and the origin of the source of the ophiolitic detrital material: from the north or northwest (i.e. from the Lycian Nappes), or from the east (i.e. from 
the Antalya Nappes). We have reinvestigated the Çatallar Basin in order to check both models with a $1 / 25,000$ scale mapping, a reappraisal of the facies analysis and a precise stratigraphy based on planktic foraminifera.

\section{The Çatallar Basin}

\subsection{Geological setting (Fig. 1, Fig. 2, Fig. 3, Fig. 4 and Fig. 5)}

The Çatallar Basin is located $20 \mathrm{~km}$ north of Finike and was connected with the Salur and Kasaba Basins during the Miocene (Fig. 1). The Çatallar Basin was deformed by Late Miocene to Pliocene tectonic events which affected SW Turkey (Aksu Phase, [Poisson, 1977], [Frizon et al., 1995] and [Poisson et al., 2003a]). As a result, the Çatallar Basin was isolated from the adjacent basins, and the Bey Dağları and Susuzdağ platform units overthrust parts of its northern and eastern margins which are now hidden (Susuzdağ Thrust, [Uysal et al., 1980] and [Şenel, 1997]) (Fig. 2).

\subsection{Lithostratigraphic type succession}

Following the first stratigraphic studies of the basin ([Poisson, 1977] and [Uysal et al., 1980]), Hayward (1982) provided a detailed description of the facies and the formations, and recognised the sedimentary interfingering of several lithological units. A complete sequence of the basin fill can be seen between Gökbük and Başkoz (Fig. 2), and a synthetic litho- and bio-stratigraphic log of the basin is presented in Fig. 3. We propose here a new interpretation of the Çatallar Basin, which includes a revision of Hayward's nomenclature, as follows:

\subsubsection{Karabayır formation}

This formation was first described on the western side of the Bey Dağları anticline (Poisson and Poignant, 1974) and consists of shallow-marine calcarenitic limestone grading upward into deeper micritic facies. The calcarenites include red algae, benthic foraminifera, echinoderms, molluscs and corals of Late Oligocene to Aquitanian age (Fig. 6A). Above, the micritic limestones contain a rich assemblage of planktic foraminifera of Early Burdigalian age. In the Çatallar Basin, this formation is present only locally but is frequently found as pebbles in the overlying conglomerates and as olistolites in the olistostromes, suggesting that the former extension of the Karabayır formation was much wider in the region (Mk in Fig. 9).

\subsubsection{Akçay formation}

The Akçay formation records the first detrital input into the basin. This formation was described near the village of Yalnız (former name: Akçay) by (Hayward, 1982) and (Hayward and Robertson, 1982). The base consists of turbidites (Langhian), followed by debris flows and olistostromes containing ophiolitic debris. Five facies (F1: green mudstone-calcareous sandstone-carbonate alternations; F2: parallel stratified calcareous sandstone-siltstone alternations; F3: matrix-supported conglomerate; F4: olistostromes; F5: limestone breccia) have been identified within the Akçay formation and are described in detail in Table 1 and illustrated in Fig. 6, Fig. 7 and Fig. 8. The depositional environment of the Akçay formation indicates deep marine conditions, as suggested by turbiditic sandstones (F1 and F2, Fig. 6BF) and olistostromes (F4, Fig. 7C-D). The large predominance of planktic foraminifera indicates a basin several hundred meters deep. In the shallower parts of the basin, matrix- 
supported conglomerates (F3) representing fan deltas (Fig. 7A-B) and breccias from colluvial cones (F5, Fig. 7E-F) are also present.

\subsubsection{Băgbeleni formation}

This conglomeratic formation was described by Hayward (1982) as a member of his Kemer formation. The type section is situated between the villages of Çatallar and Bağbeleni (Fig. 2). Two facies (F6: clast- to matrix-supported imbricated conglomerate and F7: clast-supported conglomerate) are described within the Bağbeleni formation (Table 1), and illustrated in Fig. 7 and Fig. 8.

Contrasting with the deep marine environment of the Akçay formation, the environments of the Bağbeleni formation are generally shallower, and end with shallow-marine to sub-aerial deposits. The age of deposition is younger, most probably Late Langhian to Serravallian, reaching the Tortonian at the top (Fig. 3). The Bağbeleni formation is dated indirectly through reworked pebbles, and by the dating of mudstones and sandstones considered as a lateral facies equivalent in the southeastern part of the basin (see sections Sections 1 and 2 in Fig. 4a). To the north (Başkoz and Günçalı Yayla), the age of the Bağbeleni formation derives from mudstone intercalations containing planktic microfaunas (sections 3-5 in Fig. 4a).

\subsection{Lateral variations}

Both formations described above were initially mapped within the Çatallar Basin but have been followed farther to the north, although they may not be present altogether in each section. North of Çatallar village, the Susuzdağ Thrust hides a substantial part of the basin, nevertheless, in the northwestern area, similar successions are present (Fig. 4b, sections 6-8), with alternating mudstones and sandstones (Akçay formation), followed by an olistostrome in the Arif area and, further to the north, by thick conglomerates (Bağbeleni formation) which include pebbles of gabbros, serpentinites, peridotites (up to $30-40 \mathrm{~cm}$ in size), radiolarites, metamorphic rocks and various carbonates (F6 and F7, Fig. 8). A similar succession is present near Başkoz village and in the Hördübek and Günçalı Yaylas (Fig. 2), and extends further west in the Kasaba Basin where it joins other coarse detritals issued from two fan deltas near Ortabağ and Doğantaş villages (Fig. 1). The latter also contain ophiolitic pebbles derived from the Lycian Nappes ([Önalan, 1979], [Hayward, 1982] and [Hayward and Robertson, 1982]).

\subsection{Biostratigraphy}

The stratigraphy in the Çatallar Basin is mainly based on planktic foraminifera assemblages (Table 2), and accessorily on benthic microfauna in the neritic limestones of Aquitanian age. In their new biostratigraphic and chronostratigraphic scale, Iaccarino and Premoli Silva, 2005 define the Langhian stage differently from that of Iaccarino (1985): Langhian is calibrated from 15.9 to 13.6 Ma. It begins with the sicanus FO (first occurrence) and ends just before the periferoronda LO (last occurrence). In this scale, Orbulinas appear in the middle part of the stage. In Iaccarino (1985), Langhian also begins with the sicanus FO, but is shorter, and ends with the appearance of Orbulinas, precisely between $O$. suturalis and O. universa FO's. In order to ensure an easier correlation with other Miocene basins in Turkey and in the eastern Mediterranean region, we follow the stratigraphic concept of Iaccarino (1985) in this paper. The chronostratigraphy is based on the biozones (N5 to N14 in Table 2) defined by planktic 
assemblages, but the stages boundaries (Burdigalian, Langhian, Serravallian), are only indicative as their limits are still under discussion.

Previous studies ([Poisson, 1977], [Uysal et al., 1980] and [Poisson and Akay, 1981] used by Hayward (1982) provided the first stratigraphical data for the base of the basin in the Çatallar-Gökbük area and showed that an important gap (Early Miocene) existed between Oligocene and Langhian deposits. However, this gap seems only local as limestones of latest Oligocene to Aquitanian age are present within the Karabayır formation. However, in many places, the Lower Miocene deposits were eroded during the Burdigalian-Langhian transgression (Poisson and Akay, 1981) and only fragments are present as reworded pebbles in the Langhian conglomerates.

Burdigalian deposits (muddy limestones) were also largely eroded and reworked during Langhian. The precise transition from Aquitanian to Burdigalian (Fig. 4a section 3, sample 83: N5 zone) is present within a reworked block of planktic limestone in the lowermost olistostrome of the Akçay formation, near Çatallar village. Thus, most of the Akçay formation and the lower part of the Bağbeleni formation are Langhian in age, and exhibit a high rate of detrital sedimentation (Table 1 and Fig. 3). The end of the basin infill occurred during Serravallian, as shown in the upper half of the Bağbeleni formation and its lateral equivalents. Only one sample, situated in the upper part of the Bağbeleni formation (Fig. 4a section 1, sample 52: N14 zone) and containing Globigerina nepenthes associated with Neogloboquadrina praeatlantica could be attributed to Early Tortonian. Unfortunately, the uppermost deposits of the Çatallar Basin are hidden under the Susuzdağ Thrust.

\section{Origin of the olistolites and of the ophiolitic detritals in the Çatallar Basin: discussion}

As concerns the origin of the detritals in the Çatallar Basin and in the adjacent Kasaba and Salur Basins, various arguments have been considered. Among them, the lithology of reworked materials, sedimentological data and possible source rocks have been spotted in the nearby platform carbonates and in the allochthonous units situated farther away ([Poisson and Akay, 1981] and [Hayward, 1982]).

\subsection{Origin of the large carbonate olistolites and of the debris flows}

Owing to their size (F4, Fig. 7C-D), the large carbonate olistolites most probably derive from the nearby carbonate platforms in the Alacadağ and in the Pancarlı Dağ (Fig. 2 and Fig. 9) where similar facies of Upper Cretaceous Globotruncana limestones, Eocene nummulitic limestones and planktic Burdigalian micrites are present.

West of Gökbük village (Fig. 2), shortly travelled debris-flows containing only carbonate pebbles with coral fragments in a sandy matrix most probably have also a local origin such as Alacadağ to the west of the Çatallar Basin. Higher, the debris flows contain various materials such as gabbros and other ophiolitic debris of distant origin mixed with locally derived carbonates (Aquitanian algal limestones, coral fragments, Eocene and Cretaceous limestones), embedded in a sandy matrix (facies F3, Fig. 7A-B). Several occurrences are present in debris flows near Çatallar village along the new road to Finike, at the cross section of the Elmalı and Kasaba roads, and in the Yazır corridor (Fig. 2). 


\subsection{Origin of the ophiolitic clasts}

\subsubsection{Arguments from paleogeographic data}

The origin of the ophiolitic clasts is controversial. On the basis of similar ages and type of deposition (olistostromes with coarse pebbles), Poisson and Akay (1981) have compared the Çatallar olistostrome with the Kemer fan delta in the Kasaba Basin (Fig. 2), and suggested that both should have the same origin, i.e. derived from the Lycian Nappes located to the north. On the opposite, Hayward and Robertson (1982) relying on flow directions measurements in the region favoured an eastern origin for the Çatallar debris flows, i.e. from the Antalya units. However, their conclusion is based on the combination of two distinct sets of data, one from the Çatallar Basin itself, and another set measured in the Salur Basin with a poorer stratigraphic control. Our measurements are in agreement with those concerning the Çatallar Basin (i.e. showing a northern origin), and precise ages (Langhian-Serravallian) are provided here for the related detritals. In contrast, the age of the coarse detritals in the Salur Basin, where the most significant eastern directions recorded by Hayward and Robertson (1982) come from, is not tightly constrained and is possibly younger in part, as suggested by the Late Miocene thrust of the Antalya units situated immediately above. Hence, in spite of the similar aspect of the Miocene conglomerates in the Çatallar and in the Salur basins, two distinct detrital sources are probably present, and require that both sets of data should be considered separately.

The Çatallar olistostrome and the fan deltas in the Kasaba Basin have the same age (Langhian), which is precisely the age of the latest translation of the Lycian Nappes onto the Bey Dağları, as shown by the youngest deposits in the Lycian Basin in front, which are polymictic conglomerates deriving from the arriving Lycian Nappes (Fig. 9A). These conglomerates contain abundant ophiolitic blocks and pebbles and were part of sub-emergent fan deltas, including coral reefs from place to place ([Poisson, 1977], [Gutnic et al., 1979], [Hayward et al., 1996], [Tuzcu and Karabıyıkoğlu, 2001] and [Karabıyıkoğlu et al., 2005]). The direction of transport of this coarse material is grossly from north to south (or NW to SE) towards the Kasaba Basin, through the Susuzdağ platform. Unfortunately, remnants of such deposits are absent in the central part of the Susuzdağ owing to the erosion which followed the Upper Miocene-Pliocene and Recent uplifts in the area. In contrast, the distal and deepest parts of the fan deltas are preserved along the northern margin of the Kasaba Basin near Kemer (western end) and in the Ortabağ and Doğantaş area (eastern end of the Kasaba Basin, Fig. 1). In these areas, the fan deltas are transitional with more distal facies (mudstones and graded sandstones) situated in the central part of the basin. The frequent intercalation of an abundant shelly fauna and plant remains with poor planktic microfauna suggests a shallowmarine environment, close to a landmass. The detrital connection can be followed from the Kasaba Basin to the Çatallar Basin, through the Yazır corridor and the Başkoz corridor, as shown by the coarse polymictic conglomerates of the Bağbeleni formation below the Susuzdağ Thrust (Fig. 1, Fig. 2 and Fig. 4). Hence, during the Langhian coarse ophiolitic debris can be traced from the front of the Lycian Nappes down to the Çatallar Basin through the Günçal1-Hördübek-Başkoz corridor (see map Fig. 1). These deposits substantiate a coeval detrital output linking the front of the Lycian Nappes to the Kasaba and the Çatallar Basins as remnants of larger fan deltas now preserved below the Susuzdağ Thrust (Fig. 9B and C).

\subsubsection{Arguments from sedimentological data}


In the Akçay formation, fine-grained distal turbidites (facies F1 and F2, Fig. 6B-F) together with in situ planktic foraminifera microfauna indicate a pro-delta to deep marine environment. The deepest part of the basin was located in S and SE. In addition, some of the current directions measured from the flute casts at the base of turbidites to the south of Yalniz village indicate paleocurrents from $\mathrm{N}$ or NE, in agreement with Hayward (1982) data. However, these data are not conclusive as in the deeper parts of the basin directions of currents could easily change. Besides, flute cast measurements from the turbidites in the southeastern part of the Çatallar Basin indicate that paleocurrent directions are scattered from NW to SE (Fig. 2).

In the Bağbeleni formation, pebble imbrications indicate paleocurrents coming from the North or NW in majority (Fig. 2), as in Hayward's data (1982). Moreover, the location of polymictic debris-flows along the northern and western borders of the Çatallar Basin also favours a northern origin of the detrital materials. This is also suggested by a change of facies from coarse to fine detritals and the decrease of the size of pebbles from NW to SE. Narrow distributary channels filled with coarse clasts in the proximal part of the fan delta near Başkoz village (NW) are replaced by finer sediments in the Yalnız area (SE).

As a conclusion concerning the origin of the clastic materials in the Çatallar Basin, most of the sedimentological data suggest a northern origin with the exception of the turbidites, which are not conclusive.

\section{Conclusions: Origin of the ophiolitic detritals and significance of the Miocene basins in SW Turkey}

The Çatallar Basin and the related outcrops of Lower-Middle Miocene age in SW Turkey appear as remnants of a former widespread sedimentary cover which spread over most if not all the southern part of the Bey Dağları Massif.

Until Early Miocene, the Çatallar area was part of the southern Bey Dağları platform as it followed the same sedimentary trends (Poisson, 1977). However, from the Burdigalian onwards, this area evolved independently, commencing with a marked subsidence similarly to the Lycian Basin but, unlike the latter, the Çatallar Basin contains Burdigalian pelagic limestones with planktic foraminifera, showing that until the transition Burdigalian-Langhian, this area remained out of reach of the ophiolitic debris and other detritals issued from the Lycian units. This suggests that some kind of trap-barrier existed in between, and was probably situated where the Susuzdağ now stands (Fig. 9A). This trap was most effective during the Early and Middle Burdigalian and prevented the northern influx of clastic materials to spread into the Kasaba and Çatallar Basins (Poisson, 1977). Early in the Langhian, however, this barrier no longer existed, indicating that the filling of the Lycian Basin was completed. Subsequently, during Langhian, Serravallian and later on, the feeding deltas migrated southwards, and detritals were shed farther, into the southern basins (Kasaba, Çatallar and Sidek Basins) (Fig. 9B).

Concerning the Çatallar Basin the presence of calcareous debris flows and olistostromes of Langhian age reflects local tectonic events which controlled part of the sedimentation. The restricted localisation of the largest calcareous olistolites (Fig. 2) along the western border of the basin, and their ages (Late Cretaceous, Middle Eocene, Early Miocene) suggest that normal faulting affected that side of the basin (Alacadağ and Pancarlı Dağ) during the Langhian. As a matter of facts, west of Akyaka a small half-graben filled with Langhian mudstones is bounded by a normal fault striking SW-NE which could have been active during 
the sedimentation. Whatever the case, such tectonic events, and the related debris flows and olistostromes, seem specific to the Çatallar Basin.

The onset of a polymictic detrital sedimentation into the Çatallar Basin (Akçay formation) during the Langhian is coeval with the latest episode of emplacement of the Lycian Nappes onto the Bey Dağları platform. Higher, the conglomerates of the Bağbeleni formation reflect shallow-marine to subaerial conditions during the Serravallian and early in the Tortonian. In agreement with the clast composition and the palaeocurrent directions, this detrital material originate from the Lycian Nappes and must have travelled a long way from the North through the southern Bey Dağları, although direct evidence is lacking (Fig. 9C). In the Kasaba Basin, the Doğantaş, Kemer and Ortabağ fan deltas also contain polymictic detritals coming from the Lycian Nappes through the Susuzdağ (see map Fig. 1). Northwest of the Çatallar Basin, the Başkoz-Hördübek and Günçalı Yayla corridor contain remnants of similar detrital bodies exhibiting similar palaeocurrent directions, thus substantiating the Lycian provenance of the ophiolitic detritals (Bağbeleni formation) which filled the Çatallar Basin during the Middle Miocene.

In a wider view, the Lycian Basin, the Kasaba Basin and the Çatallar Basin record the progressive sedimentation of north-derived polymictic detrital materials on the Bey Dağları platform, and thus may be considered as parts of a larger foreland basin to the Lycian Nappes. This interpretation seems more appropriate than a previous model (Hayward and Robertson, 1982) in which the Antalya units were considered as the only source of the Çatallar detritals, after passing through the Salur Basin situated further east. A closer examination of the latter is presently in progress.

\section{Acknowledgements}

The Akdeniz University in Antalya, the French Embassy in Ankara and ISTO in Orléans University supported the fieldwork and greatly facilitated scientific exchanges. Thin section preparations were carried out in Orléans University and in Hacettepe University in Ankara. The authors gratefully acknowledge the above institutions and thank C. Göncüoğlu, B. Varol and B. Natalin for their critical reviews and constructive comments.

\section{References}

Alonso-Zarza and Calvo, 2000 A.M. Alonso-Zarza and J.P. Calvo, Palustrine sedimentation in an episodically subsiding basin: the Miocene of the northern Teruel Graben (Spain), Palaeogeography, Palaeoclimatology, Palaeoecology 160 (1-2) (2000), pp. 1-21.

Alonso-Zarza, 2003 A.M. Alonso-Zarza, Palaeoenvironmental significance of palustrine carbonates and calcretes in the geological record, Earth Science Reviews 60 (2003), pp. 261298.

Blair and McPherson, 1994 T.C. Blair and J.G. McPherson, Alluvial fans and their natural distinction from rivers based on morphology, hydraulic processes, sedimentary processes, and facies assemblages, Journal of Sedimentary Research A64 (1994), pp. 450-489.

Blirka and Nemec, 1998 L.H. Blirka and W. Nemec, Postglacial colluvium in western Norway: depositional processes, facies and paleoclimatic record, Sedimentology 45 (1998), pp. 909-959. 
Bouma, 1962 Bouma, A.H., 1962. Sedimentology of some Flysch deposits; a graphic approach to facies interpretation. Published Ph.D. Thesis, Elsevier, 168 p.

Brunn et al., 1971 J.H. Brunn, J.F. Dumont, P.C. de Graciansky, M. Gutnic, T. Juteau, J. Marcoux, O. Monod and A. Poisson, Outline of the geology of the western Taurids. In: A.S. Campbell, Editor, Geology and History of Turkey, Petroleum Exploration Society of Libya, Tripoli (1971), pp. 225-252.

Capuzzo et al., 1997 Capuzzo, N., Wetzel, A., Niklaus, P.A., 1997. Tectonic cyclothems document the history of a Late Palaeozoic fluvial basin (Dorénaz Basin, Southwestern Switzerland). EUG (European Union of Geoscience) 9, Strasbourg, France.

Diaz-Martinez, 2007 E. Diaz-Martinez, The Sacta limestone member (early Wenlock): coolwater, temperate carbonate deposition at the distal foreland of Gondwana's active margin, Bolivia, Paleogeography, Paloeclimatology, Paleoecology 245 (1-2) (2007), pp. 46-61.

Enos, 1977 P. Enos, Flow regimes in debris flow, Sedimentology 24 (1977), pp. 133-142.

Flecker et al., 2005 Flecker, R., Poisson, A., Robertson, A.H.F., 2005. Facies and palaeogeographic evidence for the Miocene evolution of the Isparta Angle in its regional Eastern Mediterranean context. In: Kelling, G., Robertson, A.H.F., van Buchem, F. (Eds.), Cenozoic Sedimentary Basins of South Central Turkey. Sedimentary Geology, vol. 173, pp. 277-314.

Frizon et al., 1995 D. Frizon, A. Poisson, C. Aubourg and H. Temiz, Chevauchements vers l'ouest puis vers le sud, au coeur de l'angle d'Isparta (Taurus, Turquie). Conséquences géodynamiques, Bulletin de la Société Géologique de France 166 (1995), pp. 59-67.

Gutnic et al., 1979 M. Gutnic, O. Monod, A. Poisson and J.F. Dumont, Géologie des Taurides Occidentales (Turquie), Mémoire de la Société Géologique de France 137 (1979), pp. 1-112.

Hayward, 1982 Hayward, A.B., 1982. Tertiary ophiolite-related sedimentation in SW Turkey. Unpublished Ph.D. Thesis, University of Edinburgh, 420 p.

Hayward and Robertson, 1982 A.B. Hayward and A.H.F. Robertson, Direction of ophiolite emplacement inferred from Cretaceous and Tertiary sediments of an adjacent autochthon, the Bey Dağları, South-West Turkey, Geological Society of America Bulletin 93 (1982), pp. 6875.

Hayward et al., 1996 Hayward, A.B., Robertson, A.H.F., Scoffin, T., 1996. Miocene patch reefs from a Mediterranean marginal terrigenous setting in southwest Turkey. In: Franseen, E.K., Esteban M., Ward, W.C., Rouchy J.-P. (Eds.), Models for Carbonate Stratigraphy from Miocene Reef Complexes of Mediterranean regions. Society of Economic Mineralogists and Paleontologists, Concepts in Sedimentology and Paleontology, vol. 5, pp. 317-332.

Iaccarino, 1985 S.M. Iaccarino, Mediterranean Miocene and Pliocene planktic foraminifera. In: H.M. Bolli, J.B. Saunders and K. Perch-Nielsen, Editors, Plankton Stratigraphy vol. 1, Cambridge University Press (1985), pp. 283-314. 
Iaccarino and Premoli Silva, 2005 Iaccarino, S.M., Premoli Silva, I., 2005. Practical Manual of Oligocene to Middle Miocene Planktonic Foraminifera. International school on planktonic foraminifera 4th course, Perugia, 2005.

Karabıyıkoğlu et al., 2005 M. Karabıyıkoğlu, S. Tuzcu, A. Çiner, M. Deynoux, S. Örçen and A. Hakyemez, Facies and environmental setting of the Miocene coral reefs in the LateOrogenic fill of the Antalya Basin, Western Taurids, Turkey. In: G. Kelling, A.H.F. Robertson and F. van Buche, Editors, Cenozoic Sedimentary Basins of South Central Turkey, Sedimentary Geology 173 (1-4) (2005), pp. 345-371.

Mack et al., 2000 G.H. Mack, D.R. Cole and L. Trevino, The distribution and discrimination of shallow, authigenic carbonate in the Pliocene-Pleistocene Palomas Basin, southern Rio Grande rift, Geological Society of America Bulletin 112 (2000), pp. 643-656.

Mann and Horwitz, 1979 A.W. Mann and R.C. Horwitz, Groundwater calcrete deposits in Australia: some observations from Western Australia, Journal of the Geological Society of Australia 26 (1979), pp. 293-303.

Nemec and Steel, 1984 W. Nemec and R.J. Steel, Alluvial and coastal conglomerates: their significant features and some comments on gravelly-mass-flow deposits. In: E.H. Koster and R.J. Steel, Editors, Sedimentology of Gravels and Conglomerates, Canadian Society of Petroleum Geologists Memoir (1984), pp. 1-31.

Nemec and Postma, 1993 W. Nemec and G. Postma, Quaternary alluvial fans in southwestern Crete: sedimentation processes and geomorphic evolution. In: M. Marzo and C.

Puigdfabregas, Editors, Alluvial Sedimentation vol. 17, International Association of Sedimentologists Special Publication (1993), pp. 35-276.

Nemec and Kazanc1, 1999 W. Nemec and N. Kazanc1, Quaternary colluvium in west-central Anatolia: sedimentary facies and paleoclimatic significance, Sedimentology 46 (1999), pp. 139-170.

Önalan, 1979 Önalan, M., 1979. Geology of the area. Between Elmalı and Kaş, Province of Antalya, Turkey. Ph.D. Thesis, Istanbul University Monography, vol. 29, pp. 1-139 (in Turkish with English abstract).

Pickering et al., 1986 K.T. Pickering, D.A.V. Stow, M. Watson and R.N. Hiscott, Deep-water facies, processes and models: a review and classification scheme for modern and ancient sediments, Earth Science Reviews 22 (1986), pp. 75-174 Special Publication.

Poisson and Poignant, 1974 Poisson, A., Poignant, A.F., 1974. La formation de Karabayır, base de la transgression miocène dans la région de Korkuteli (Antalya, Turquie).

Lithothamnium pseudoramossissimum: nouvelle espèce d'algue rouge de la formation de Karabayır. General Directorate of Mineral Research and Exploration Bulletin (Ankara, Turkey), vol. 82, pp. 67-71.

Poisson, 1977 Poisson, A., 1977. Recherches géologiques dans les Taurides occidentales (Turquie). Doctorat d' Etat thesis (unpublished), Université Paris-Sud, Orsay, France, 798 p. 
Poisson and Akay, 1981 A. Poisson and E. Akay, The Miocene transgression forms in the Çatallar-Gökbük Basin (Western Taurides, Turkey), Publications of the General Directorate of the Turkish Petroleum Company 25 (1981), pp. 217-222.

Poisson et al., 2003a A. Poisson, R. Wernli, E.K. Sağular and H. Temiz, New data concerning the age of the Aksu Thrust in the south of the Aksu valley, Isparta Angle (SW Turkey): consequences for the Antalya Basin and the Eastern Mediterranean, Geological Journal 38 (2003), pp. 311-327.

Poisson et al., 2003b A. Poisson, F. Yağmurlu, M. Bozcu and M. Şentürk, New insights on the tectonic setting and evolution around the apex of the Isparta Angle (SW Turkey), Geological Journal 38 (2003), pp. 257-282.

Robertson, 2000 A.H.F. Robertson, Mesozoic-Tertiary tectonic-sedimentary evolution of a south Tethyan oceanic basin and its margin in southern Turkey. In: E. Bozkurt, J.A. Winchester and J.D.A. Piper, Editors, Tectonics and Magmatism in Turkey and the surrounding Area vol. 173, Geological Society, London (2000), pp. 7-138 Special Publication.

Robertson et al., 2003 A.H.F. Robertson, A. Poisson and Ö. Akınc1, Developments in research concerning Mesozoic-Tertiary Tethys and Neotectonics in the Isparta Angle, SW Turkey, Geological Journal 38 (2003), pp. 195-234.

Şenel, 1997 Şenel, M., 1997. Geological Maps of Turkey at the scale of 1/250.000, Sheets Fethiye and Antalya. General Directorate of Mineral Research and Exploration (Ankara, Turkey) (in Turkish).

Tuzcu and Karabıyıkoğlu, 2001 Tuzcu, S., Karabıyıkoğlu, M., 2001. Paleontology, Stratigraphy, Facies and Depositional Setting of the Miocene Reefs in the Western Taurids Belt, Turkey. General Directorate of Mineral Research and Exploration (Ankara, Turkey), Report No: 10438, 214 p. (in Turkish).

Uysal et al., 1980 Uysal, S., Dumont, J.F., Poisson, A., 1980. The platforms of the Western Taurides. General Directorate of Mineral Research and Exploration (Ankara, Turkey) Report No: 6861, 122 p. (in Turkish).

Westphal et al., 2004 H. Westphal, F. Böhm and S. Bornholdt, Orbital frequencies in the carbonate sedimentary record: distorted by diagenesis?, Facies 50 (2004), pp. 3-11. 


\section{Figures}

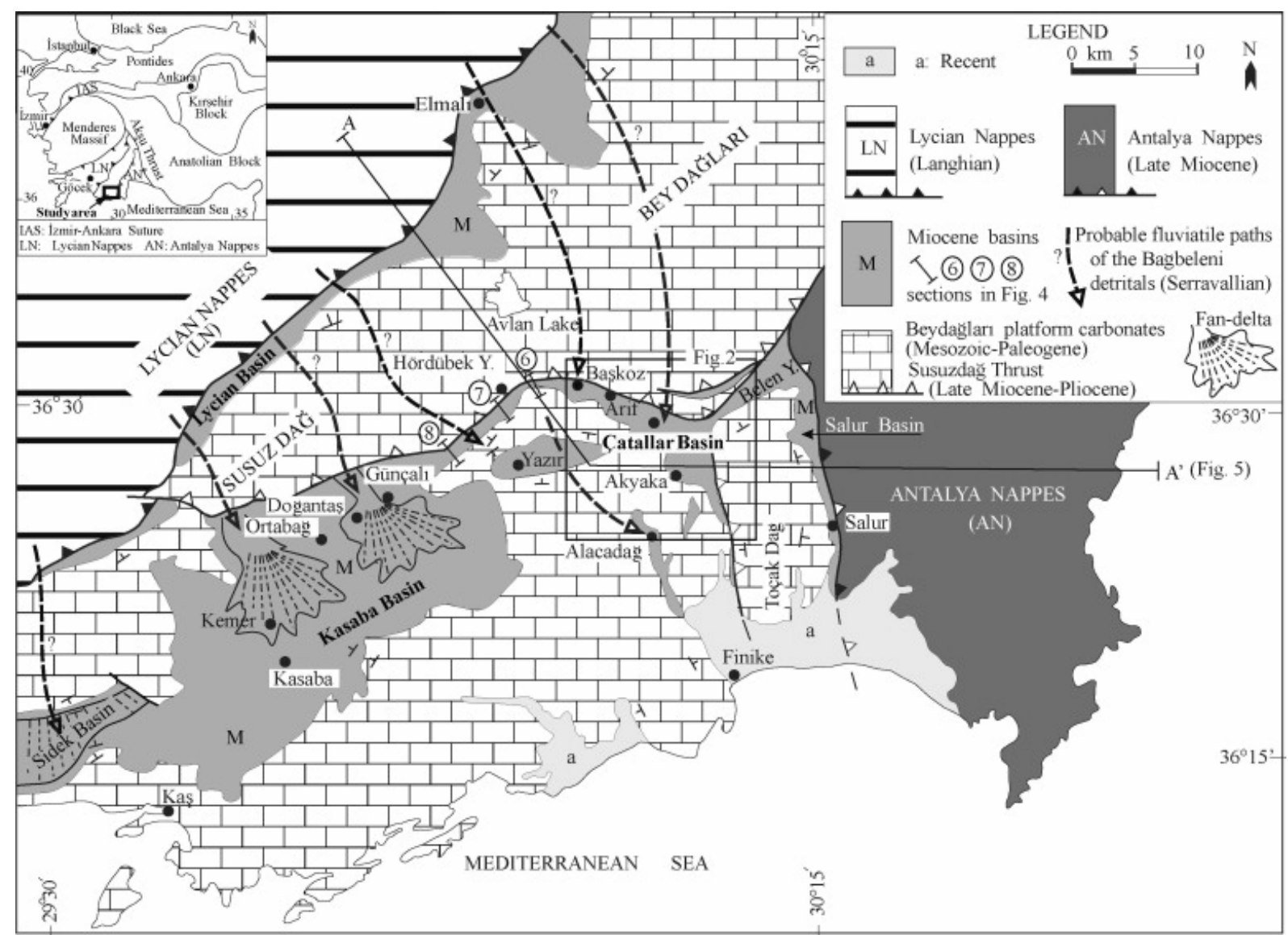

Fig. 1. Schematic map of the Neogene basins in SW Turkey and location of sections 6-8 shown in Fig. 4b. Insert: localisation of the study area. The Izmir-Ankara Suture (IAS) corresponds to the remnants of the Northern Neotethys Ocean from which the Lycian Nappes derived for a part. In this context the Menderes Massif appears as a tectonic window. The Antalya Nappes derived from the Southern Neotethys, a remnant of which is represented by the eastern Mediterranean Sea. 


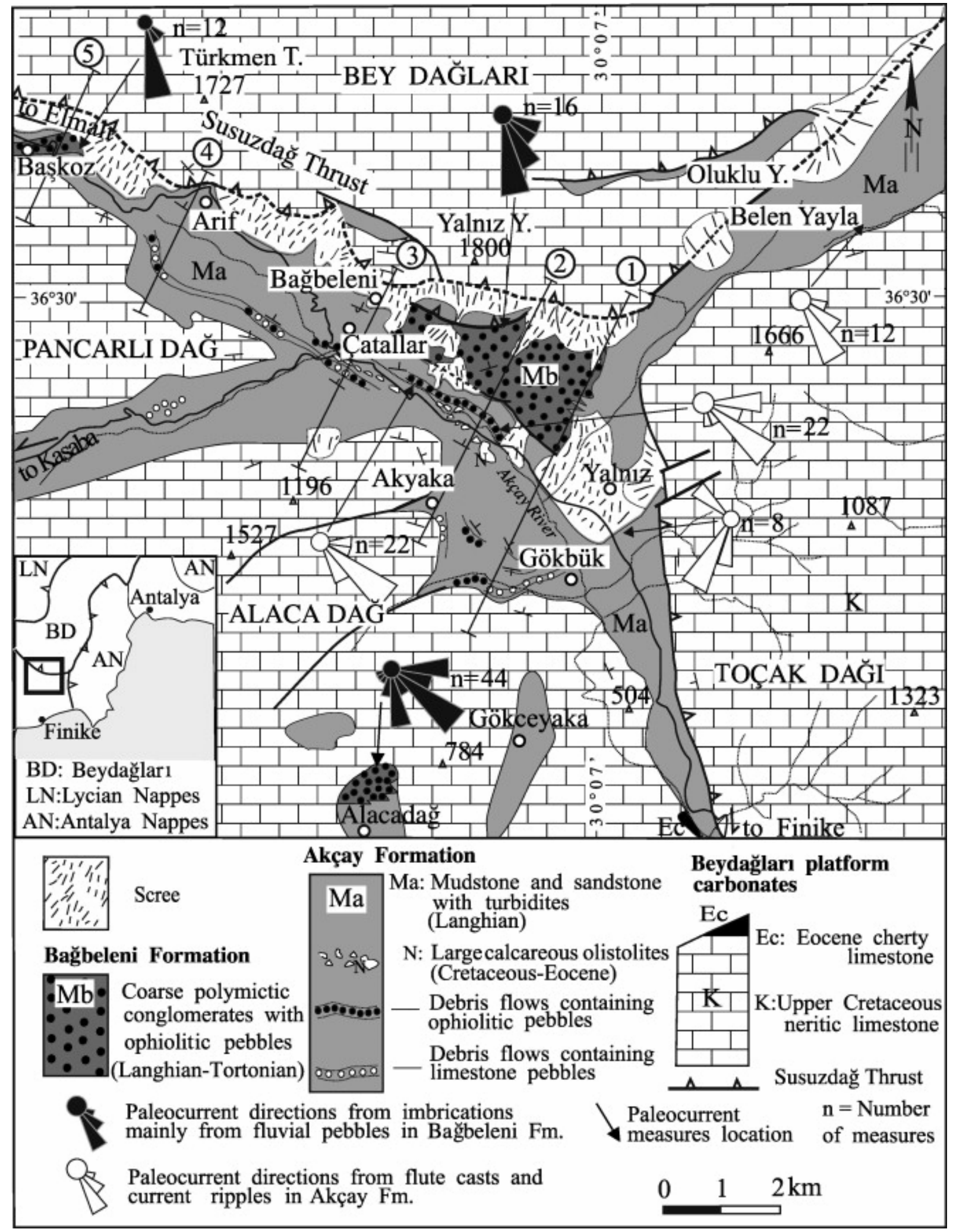

Fig. 2. Geological map of the Çatallar Basin with location of the measured palaeocurrent directions and sections 1-5 shown in Fig. 4a. 


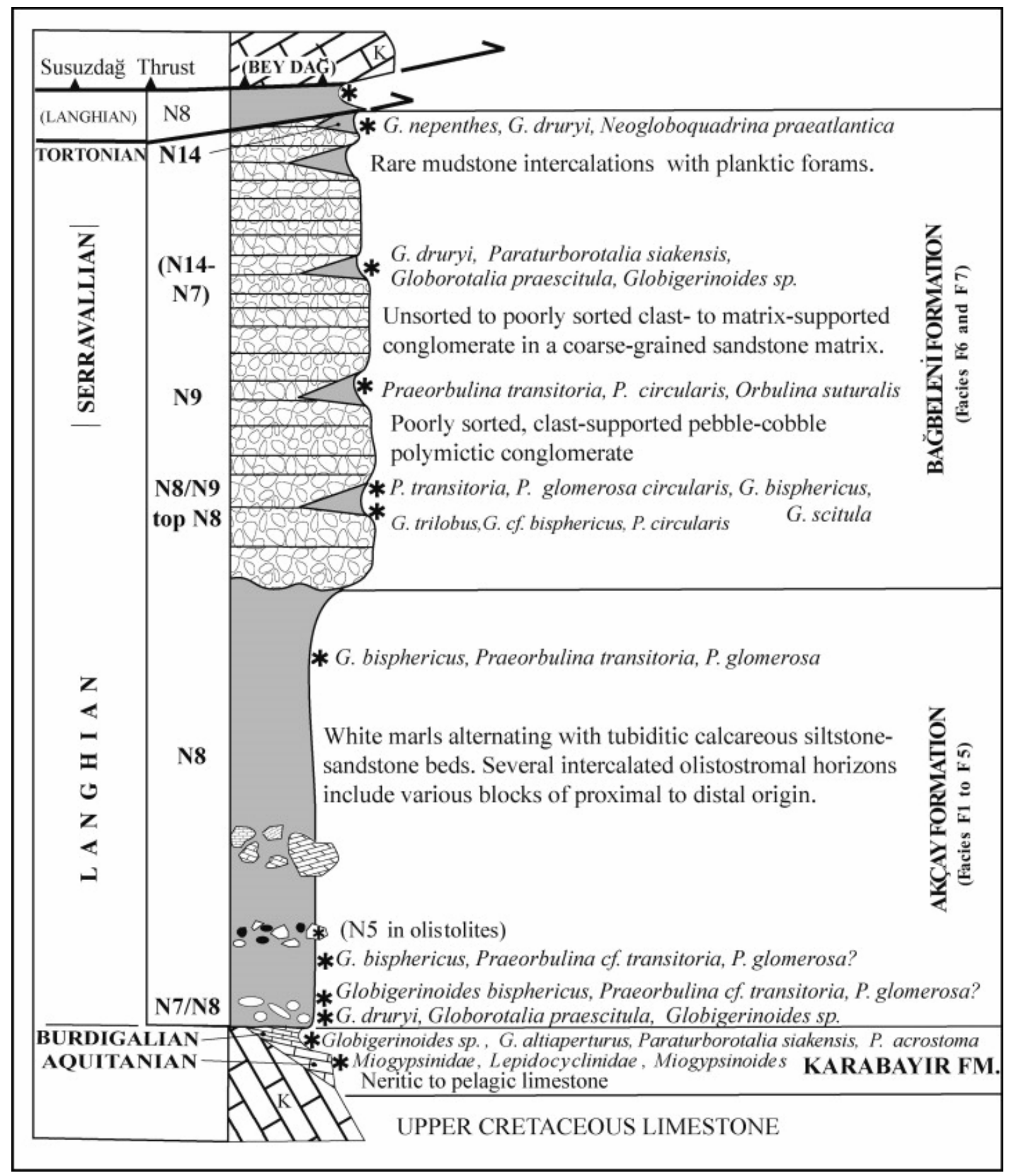

Fig. 3. Synthetic stratigraphic log of the Çatallar Basin formations showing the position of the diagnostic planktic assemblages (Biozones N5 to N14, see Table 2), and the main detrital facies (F1 to F7, see Table 1). Biozone N6 has not been characterised by planktic foraminifera. 


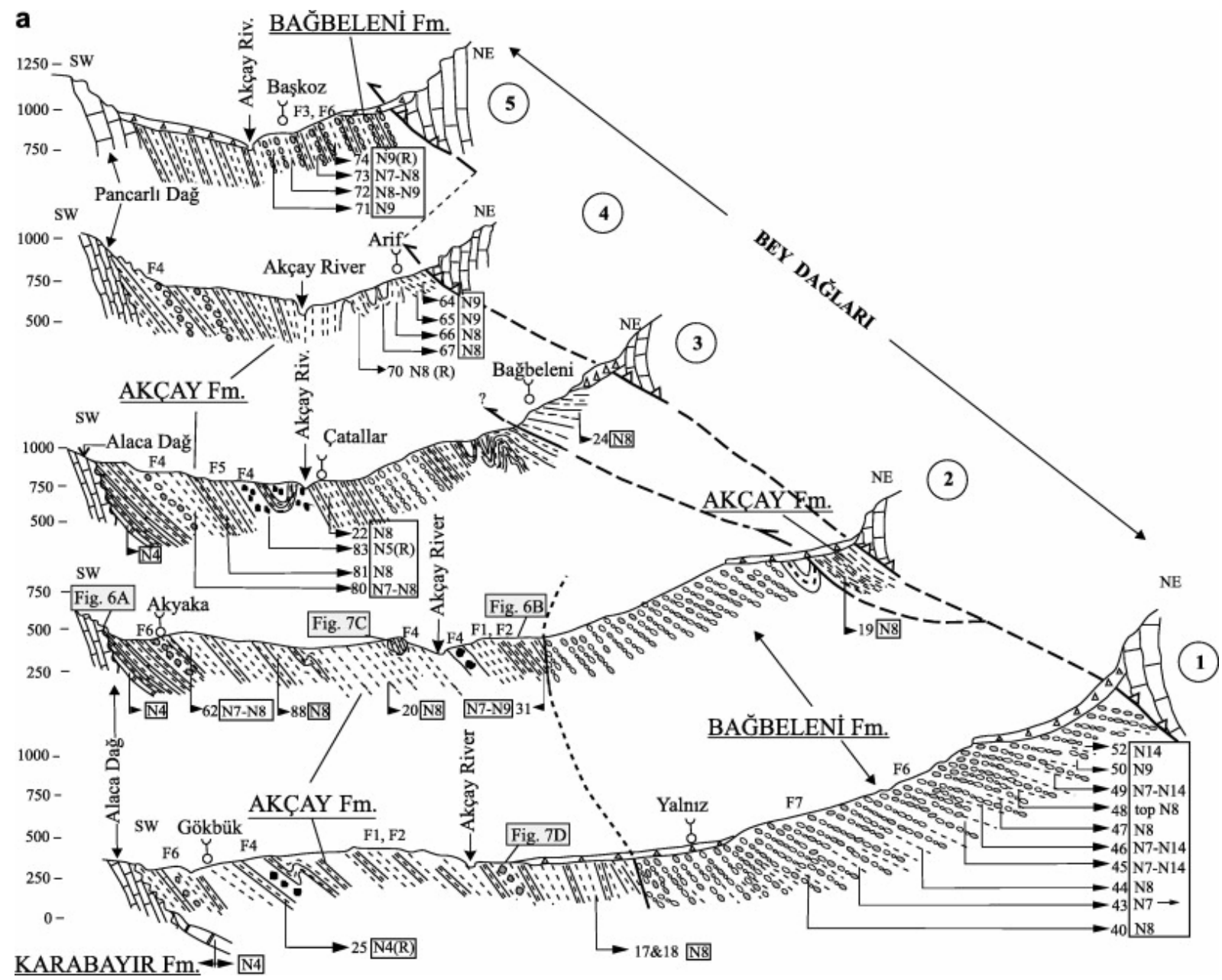




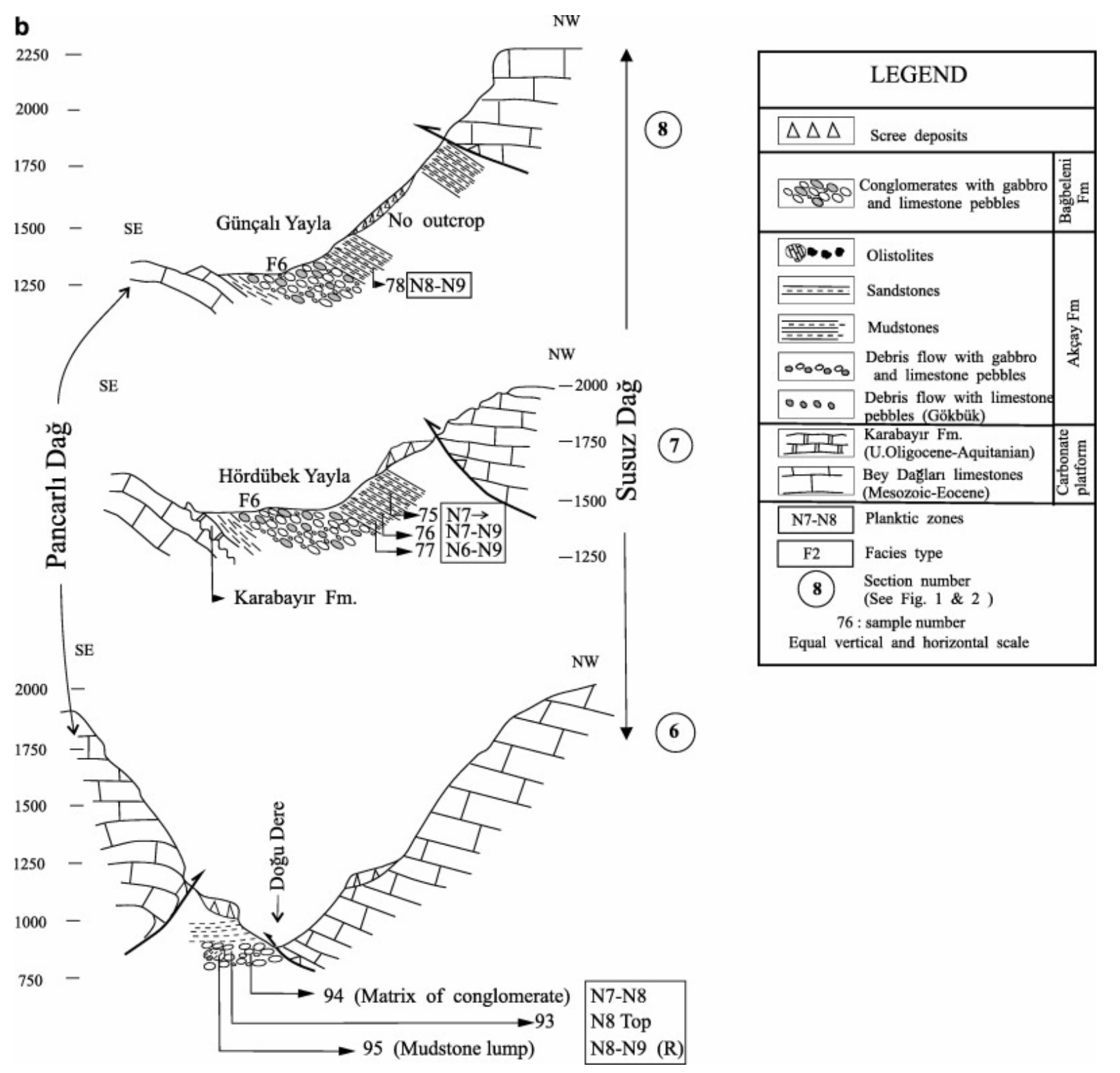

Fig. 4. (a, b) Eight cross-sections through the Çatallar Basin and the Başkoz corridor (see Fig. 1 and Fig. 2 for locations). The northern part of the Çatallar Basin is hidden below the Susuzdağ Thrust. Fossil content of samples is given in Table 2. 


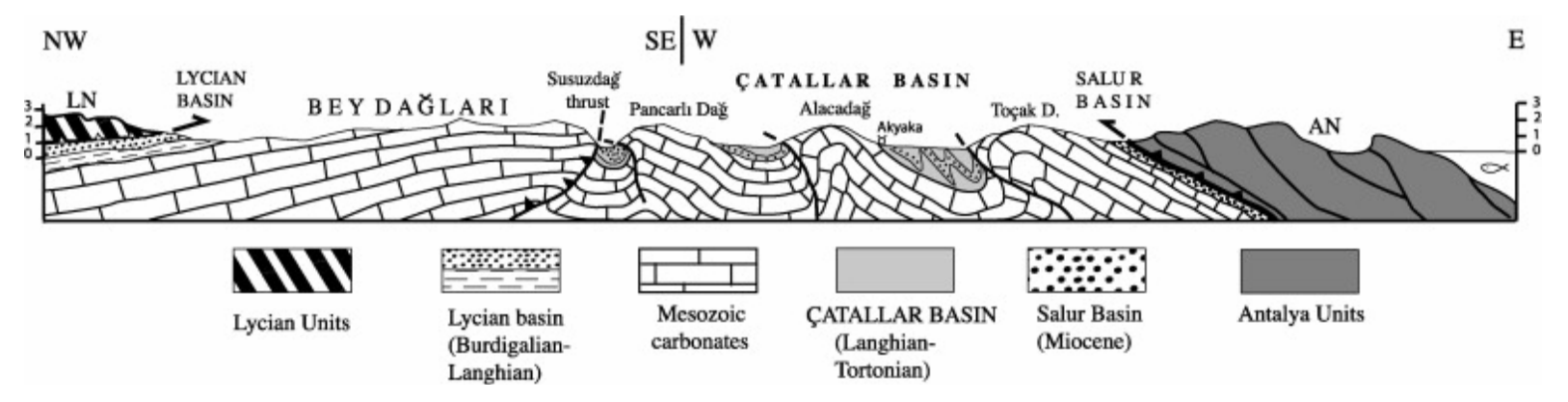

Fig. 5. Schematic cross-section from the Lycian Nappes to the Antalya Nappes (see Fig. 1 for location) showing the intermediate position of the Çatallar Basin and the Late Miocene imbrications of the Bey Dağları platform carbonates. 

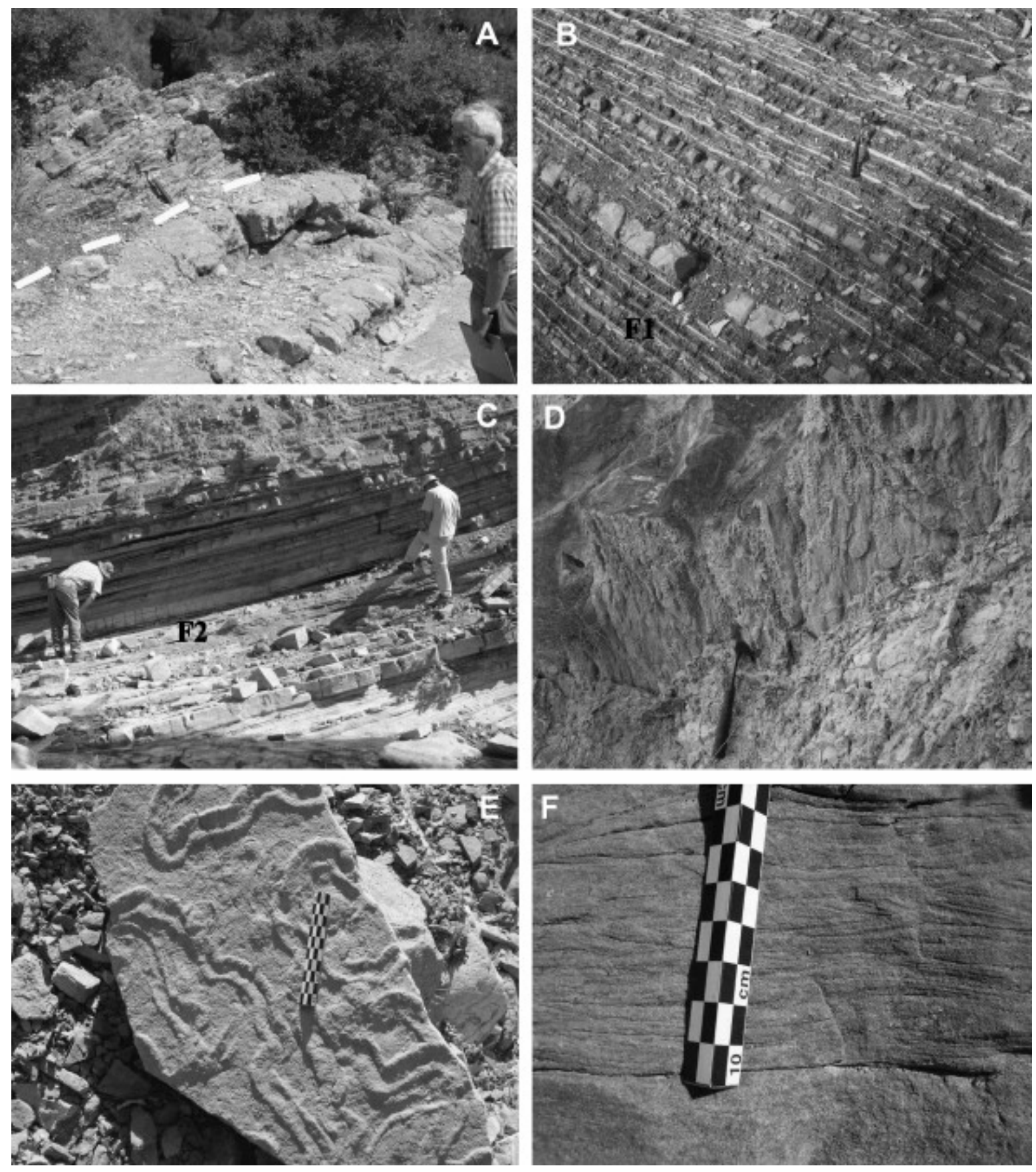

Fig. 6. (A) Field view of algal limestones of the Karabayır formation (Aquitanian) unconformably overlying Upper Cretaceous pelagic limestones. The dash line shows the boundary (location on Fig. 4a, section 2). (B) Field view of facies F1 showing alternating mudstone-sandstones and micritic carbonates. Hammer for scale. (C) General appearance of facies F2 with siltstone-fine sandstone alternations. (D) Flute casts developed under the calcareous sandstone beds. (E) Trace fossils on top of a calcareous sandstone bed. (F) Fine ripples developed on top of calcareous sandstone (Bouma Tc division). 

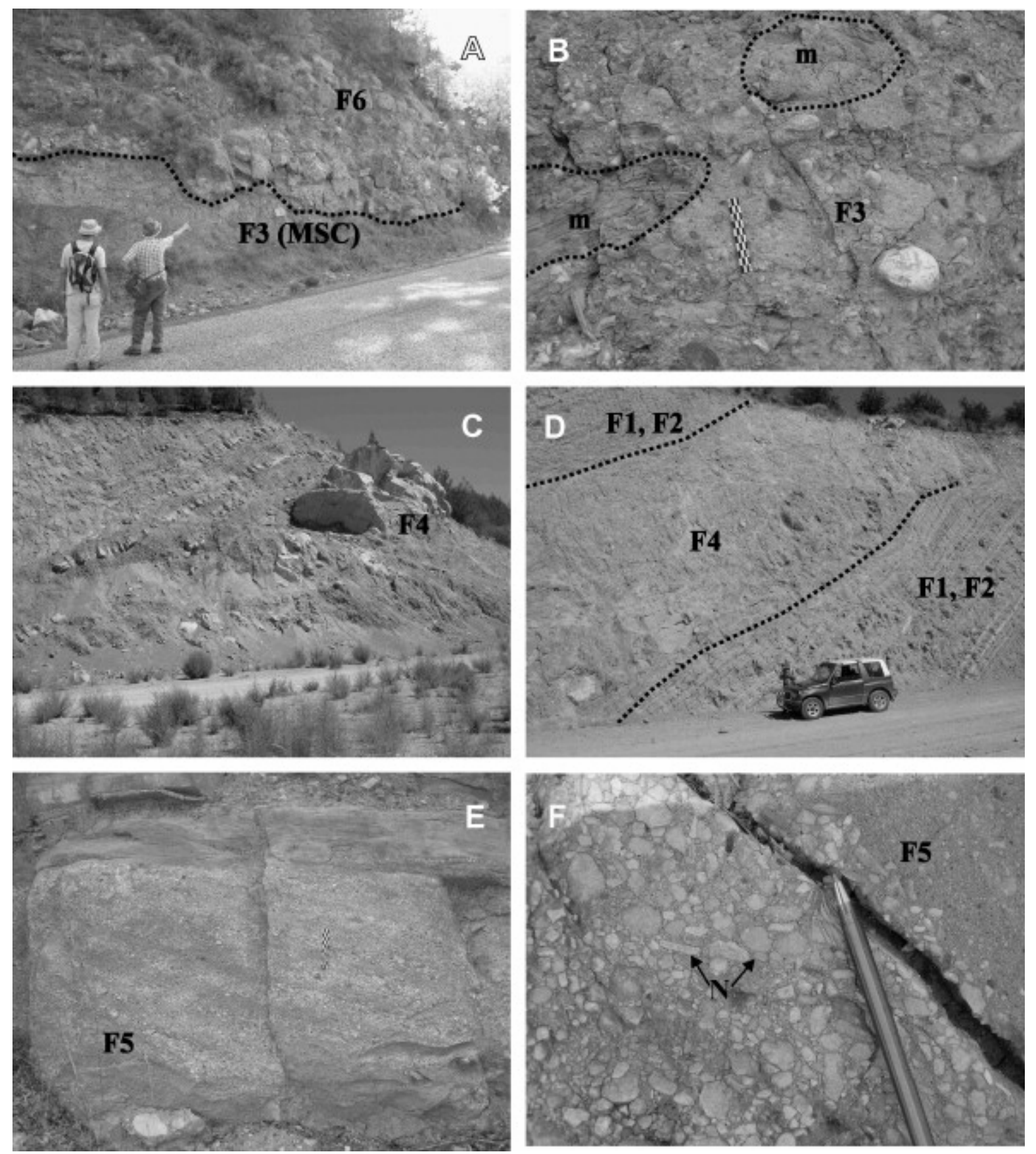

Fig. 7. (A) Field view of a matrix-supported conglomerate (MSC) facies F3 (Fig. 4a, section 5). The black line indicates the boundary with the overlying channelized clast-supported conglomerates (F6). (B) Close-up view of the pebbles and reworked mudstone fragments (m) floating in a sandy matrix (F3) (same locality). Scale is $10 \mathrm{~cm}$ long. (C) Field view of a limestone olistolite (F4) (Fig. 4a, section 2). (D) Limestone and ophiolitic blocks together with reefal pebbles (F4) sandwiched between sandstone-siltsone alternations (F2) (Fig. 4a, section). (E) Field view of the carbonate breccia facies F5 showing well-developed cross bedding. The scale in the centre is $10 \mathrm{~cm}$ long. (F) Grain supported limestone breccia with reworked Nummulites $(\mathrm{N})$. 

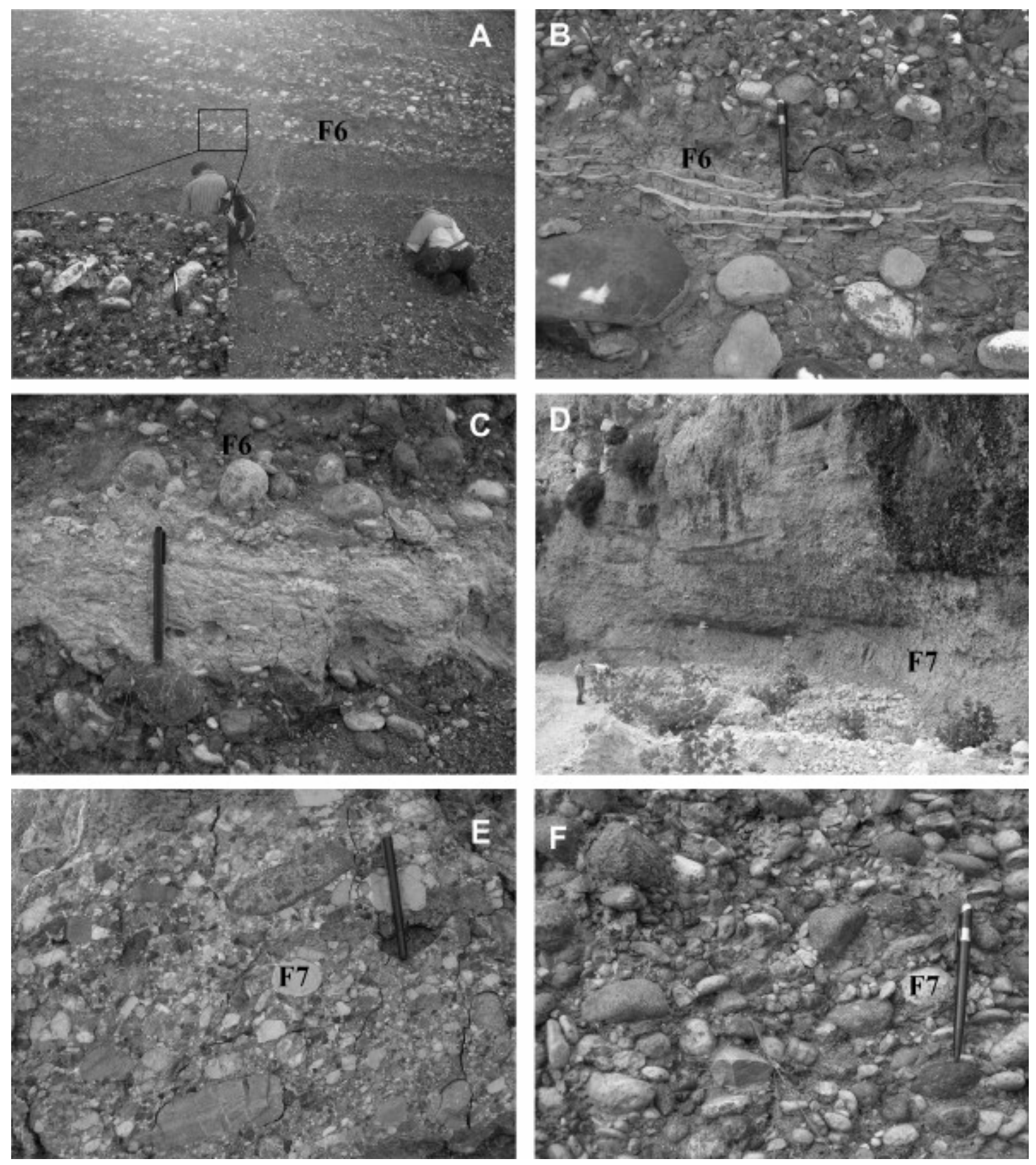

Fig. 8. (A) Imbrications in clast- to matrix-supported conglomerates (F6). The blow up picture at the bottom left corner clearly shows a paleocurrent direction from left to the right (Fig. 4a, section). (B) Red colored fluvial conglomerates (F6). Impersistent white calcrete layers indicate the development of paleosols in a relatively dry environment (same locality). (C) Thicker calcrete beds within the conglomeratic levels $(20 \mathrm{~cm}$ pencil for scale) (same locality). (D) Field views of the clast-supported conglomerate (F7) with poorly developed large-scale trough cross beds. (Fig. 4a, section 2). (E-F) Rounded radiolarite, gabbro, basalt, and limestone pebbles showing faint imbrications (same locality). 

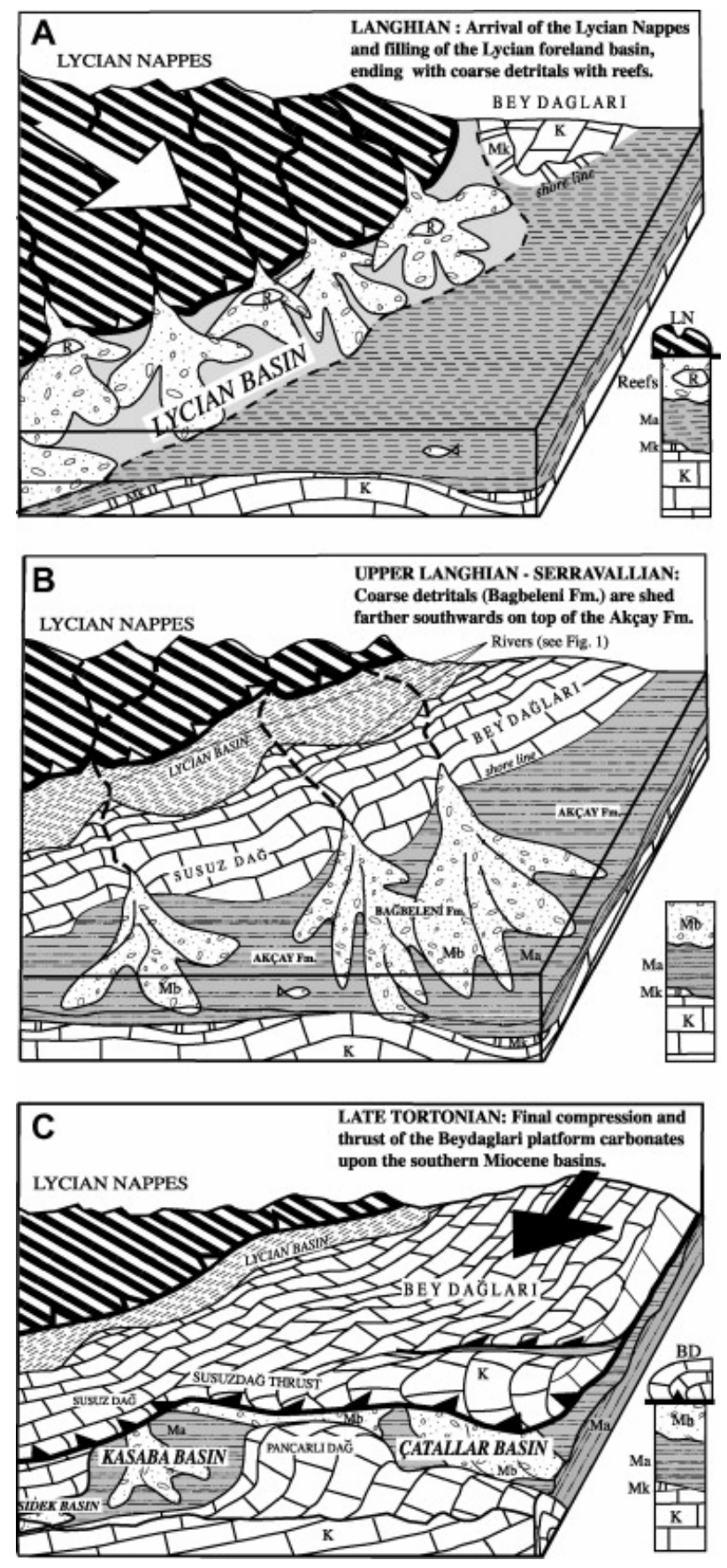

Fig. 9. Schematic evolution of the southern Bey Dağları area, from Langhian to Tortonian. (A) Langhian: in front of the advancing Lycian Nappes, the Lycian foreland basin is filled and ends with coarse detritals (fan deltas) with reefs (R). Farther away, most of the undeformed Bey Dağları platform is overlain by fine detritals (Ma, Akçay formation in the Çatallar Basin) overlying the Karabayır formation (Mk). Trap: local sediment depositional area. (B) Late Langhian and Serravallian: the Lycian Nappes, the Lycian Basin and most of the Bey Dağları platform are emerged and partly eroded. Shallow-marine to subaerial coarse detritals $(\mathrm{Mb}$, Bağbeleni formation) coming from the north are shed southeastwards on top of the Akçay formation. (C) Late Tortonian: Late Miocene to Pliocene thrusts and folds within the Bey Dağları platform delineate the present shape of the Neogene basins, and hide the northern part of the Çatallar Basin under the Susuzdağ Thrust. 


\section{Tables}

Table 1. : Description of facies F1 to F7, and their environmental interpretation

\begin{tabular}{|c|c|c|}
\hline Facies & Description & $\begin{array}{l}\text { Suggested processes and } \\
\text { environment of deposition }\end{array}$ \\
\hline $\begin{array}{l}\text { F1: Green } \\
\text { mudstone- } \\
\text { calcareous } \\
\text { sandstone- } \\
\text { carbonate } \\
\text { alternations }\end{array}$ & $\begin{array}{l}\text { Thin- to thick-bedded laterally } \\
\text { continuous, massive to faintly- } \\
\text { laminated mudstone alternating with } \\
\text { very thin micritic carbonates (Fig. } \\
6 \mathrm{~B} \text { ). Few cm to dm thick fine- to } \\
\text { medium-grained calcareous } \\
\text { siltstone-sandstone beds with rare } \\
\text { flute casts and current ripples. } \\
\text { Sandstone to mudstone ratio is about } \\
\text { 1:6. Sandstone beds have sharp to } \\
\text { wavy bases and tops with occasional } \\
\text { very faint normal grading. } \\
\text { Sandstones include red algae, } \\
\text { foraminifera, echinoderms and } \\
\text { bryozoa fragments. Organic material } \\
\text { and abundant planktic foraminifera } \\
\text { in the mudstones. } 1-3 \text { cm thick white } \\
\text { to beige micritic carbonate beds } \\
\text { show sharp contacts with the } \\
\text { underlying mudstones. Mostly } \\
\text { laterally continuous beds but some } \\
\text { pinch out within short distances } \\
\text { owing to boudinage }\end{array}$ & $\begin{array}{l}\text { Sedimentation largely from suspension } \\
\text { in quiet offshore marine environment. } \\
\text { Sandy intercalations and flute casts, } \\
\text { represent low-density turbidity } \\
\text { currents triggered by either storms or } \\
\text { tectonic instability (Pickering et al., } \\
\text { 1986). Carbonates alternating with } \\
\text { mudstones (or marls) reflect rhythmic } \\
\text { climate variations or self-organized } \\
\text { diagenesis ([Alonso-Zarza and Calvo, } \\
\text { 2000] and [Westphal et al., 2004]) }\end{array}$ \\
\hline $\begin{array}{l}\text { F2: Parallel } \\
\text { stratified } \\
\text { calcareous } \\
\text { sandstone-- } \\
\text { siltstone } \\
\text { alternations }\end{array}$ & $\begin{array}{l}\text { Mudstone-siltstone and fine- to } \\
\text { medium-grained calcareous } \\
\text { sandstone (5-50 cm to } 1 \mathrm{~m} \text { thick) } \\
\text { alternations (Fig. } 6 \mathrm{C} \text { ). Frequent } \\
\text { amalgamation of thickening up } \\
\text { sandstone beds. Flat to irregular } \\
\text { bases and up to } 10 \mathrm{~cm} \text { long flute and } \\
\text { groove casts and large load casts in } \\
\text { some beds (Fig. 6D). Planar to wavy } \\
\text { bed tops with lingoid ripples and } \\
\text { vertical but mostly horizontal } \\
\text { burrows on the upper surfaces (Fig. } \\
\text { 6E). Mostly massive beds with } \\
\text { occasional Bouma divisions of Ta } \\
\text { and Tb and abundant Tc and Td } \\
\text { (Fig. 6F). Some water escape and } \\
\text { slump structures and sand dykes. } \\
\text { Well-rounded sandstone grains and } \\
\text { often broken fragments of benthic } \\
\text { and planktonic foraminifers }\end{array}$ & $\begin{array}{l}\text { Rapid deposition from highly } \\
\text { concentrated turbidity currents, } \\
\text { followed by deposition from } \\
\text { suspension fall-out during "normal" } \\
\text { quiet-water conditions after the } \\
\text { density flow event (Bouma, 1962). } \\
\text { Thick turbiditic deposits record active } \\
\text { erosional processes in the backland } \\
\text { due to tectonic events accompanied by } \\
\text { an active subsidence in the basin. Post } \\
\text { depositional deformation, and } \\
\text { synsedimentary instability are inferred } \\
\text { from water escape and slump } \\
\text { structures }\end{array}$ \\
\hline
\end{tabular}




\begin{tabular}{|c|c|c|}
\hline Facies & Description & $\begin{array}{l}\text { Suggested processes and } \\
\text { environment of deposition }\end{array}$ \\
\hline & $\begin{array}{l}\text { (biocalcarenite). } 1 \text { to } 15 \mathrm{~cm} \text { thick, } \\
\text { green to grey colored mudstone } \\
\text { intervals with Lepidocyclines, } \\
\text { Amphistegines, Miogypsina and } \\
\text { Bryozoa. Few laterally } \\
\text { discontinuous, } 3-5 \mathrm{~cm} \text { thick, plant } \\
\text { debris accumulations }\end{array}$ & \\
\hline $\begin{array}{l}\text { F3: Matrix- } \\
\text { supported } \\
\text { conglomerate }\end{array}$ & $\begin{array}{l}\text { Massive, thickly bedded (1-3 m) } \\
\text { and poorly sorted conglomerate } \\
\text { composed of pebbles floating in a } \\
\text { sandy-muddy matrix (Fig. 7A). } \\
\text { Tabular to lenticular beds bounded } \\
\text { by flat bases and irregular to wavy } \\
\text { tops, laterally thinning away in } \\
\text { several tens of meters. Grey to } \\
\text { yellow and sometimes red matrix } \\
\text { composed of varying mixtures of } \\
\text { sand and clay-sized material. Clast- } \\
\text { matrix ratio varies locally but is } \\
\text { generally around } 1: 5 \text {. Polygenic and } \\
\text { disorganized conglomerate with no } \\
\text { apparent clast fabric. Sub- to well } \\
\text { rounded } 1-2 \text { cm to } 10-15 \text { cm sized } \\
\text { unsorted clasts. Reworked mudstone } \\
\text { fragments containing abundant } \\
\text { planktic foraminifera (Fig. } 7 \mathrm{~B} \text { ). Few } \\
\text { crudely developed normal to inverse } \\
\text { grading }\end{array}$ & $\begin{array}{l}\text { Deposition in subaerial (associated } \\
\text { with red matrix) to subaqueous } \\
\text { (associated with foraminifera bearing } \\
\text { reworked grey mudstone) cohesive } \\
\text { debris-flows in various parts of a fan } \\
\text { delta. The matrix-supported } \\
\text { framework, the absence of } \\
\text { sedimentary structures and fabrics } \\
\text { indicate gravity-induced deposition en } \\
\text { masse. Clayey matrix and clasts } \\
\text { floating within the beds indicate rapid } \\
\text { deposition from high-viscosity flows } \\
\text { with matrix strength ([Enos, 1977], } \\
\text { [Nemec and Steel, 1984] and [Nemec } \\
\text { and Postma, 1993]) }\end{array}$ \\
\hline $\begin{array}{l}\text { F4: } \\
\text { Olistostromes }\end{array}$ & $\begin{array}{l}\text { Chaotic mixture of large isolated } \\
\text { blocks (olistolites) embedded into } \\
\text { mudstone to fine-grained deposits } \\
\text { with occasional evidence of } \\
\text { deformed beds underneath. The } \\
\text { different lithologies of the blocks } \\
\text { imply various source areas. In a } \\
\text { lower olistostrome near Gökbük (see } \\
\text { map Fig. 2), the olistoliths are } \\
\text { exclusively calcareous, among } \\
\text { which reef fragments (probably } \\
\text { Aquitanian) and Cretaceous blocks } \\
\text { are predominant. The largest blocks, } \\
\text { up to } 60 \text { m high, made of late } \\
\text { Cretaceous wackestones with } \\
\text { planktonic organisms and Eocene } \\
\text { nummulitic packstones are } \\
\text { conspicuous south of Çatallar } \\
\text { village, along the road to Finike }\end{array}$ & $\begin{array}{l}\text { Very large isolated blocks (olistolites) } \\
\text { classically represent rock falls } \\
\text { (Pickering et al., 1986), and are } \\
\text { possibly related to failure of active } \\
\text { fault scarps that existed nearby, } \\
\text { although none has been identified in } \\
\text { the Çatallar Basin yet. They strongly } \\
\text { suggest a proximal origin. In contrast, } \\
\text { pebbles floating in the muddy-sandy } \\
\text { matrix are interpreted as debris-flows } \\
\text { (olistostrome), coming from a more } \\
\text { distant source. They result from } \\
\text { downslope mass-transport } \\
\text { resedimentation of unconsolidated } \\
\text { siliciclastic sediments (Diaz-Martinez, } \\
\text { 2007) }\end{array}$ \\
\hline
\end{tabular}




\begin{tabular}{|c|c|c|}
\hline Facies & Description & $\begin{array}{l}\text { Suggested processes and } \\
\text { environment of deposition }\end{array}$ \\
\hline & $\begin{array}{l}\text { (Fig. 7C). Smaller blocks and sub- to } \\
\text { well-rounded ophiolitic pebbles (5- } \\
20 \mathrm{~cm} \text { in diameter) of serpentinite, } \\
\text { corals reefs, gabbros and radiolarites } \\
\text { are observed in different parts of the } \\
\text { basin. The overlying and underlying } \\
\text { deposits are generally parallel } \\
\text { stratified mudstone-sandstone } \\
\text { intercalations classified as facies F1 } \\
\text { and F2 (Fig. 7D) }\end{array}$ & \\
\hline F5: Breccia & $\begin{array}{l}\text { Chaotic assemblages of matrix- to } \\
\text { clast-supported breccia consisting of } \\
\text { very angular to subrounded, fine- to } \\
\text { medium-grained ( } 0.5-3 \mathrm{~cm}) \\
\text { fragments. Limestone clasts } \\
\text { predominate but clasts of ophiolites, } \\
\text { quartz, gabbros and radiolorites may } \\
\text { be locally abundant. Thin- to thick- } \\
\text { bedded ( } 0.5-1 \mathrm{~m} \text { ) and laterally } \\
\text { extensive tabular units with sharply } \\
\text { defined flat bases and tops. Some } \\
\text { local cross-stratified units (Fig. } 7 \mathrm{E}) \text {. } \\
\text { Clast shapes vary, but blades are } \\
\text { common. Occasional normal grading } \\
\text { within the clast-supported beds. Red } \\
\text { and/or beige fine-grained limestone } \\
\text { clasts or red to lime mudstone } \\
\text { matrix. The lime mudstone locally } \\
\text { contain reworked Eocene benthic } \\
\text { foraminifers (Nummulites) (Fig. } 7 \mathrm{~F} \text { ) }\end{array}$ & $\begin{array}{l}\text { Sub-aerial and sub-aqueous processes } \\
\text { and environments of deposition in } \\
\text { basin margin colluvial cones. The } \\
\text { breccias indicate gravity induced mass } \\
\text { transport including rock falls and } \\
\text { slides on steep slopes ([Blirka and } \\
\text { Nemec, 1998] and [Nemec and } \\
\text { Kazanc1, 1999]). Lime mudstone with } \\
\text { marine fossils represents deposition in } \\
\text { a near shore environment. Red matrix- } \\
\text { supported breccia indicates a } \\
\text { terrestrial origin }\end{array}$ \\
\hline $\begin{array}{l}\text { F6: Clast- to } \\
\text { matrix-supported } \\
\text { imbricated } \\
\text { conglomerates }\end{array}$ & $\begin{array}{l}\text { Unsorted to poorly sorted clast- to } \\
\text { matrix-supported conglomerate } \\
\text { forming laterally extensive, few m } \\
\text { thick, tabular to broadly lenticular } \\
\text { units. Internal horizontal or crudely } \\
\text { developed oblique bedding. Some } \\
\text { broadly lenticular units consist of } \\
\text { tabular low angle and concave up } \\
\text { cross-bedded sets eroded by } \\
\text { horizontally bedded tabular units. } \\
\text { Flat bases with some scouring. } \\
\text { Rounded to subangular limestone, } \\
\text { radiolarite, gabbro, basalt, and chert } \\
\text { clasts ( } 1-3 \text { cm to } 8-10 \mathrm{~cm} \text { ). } \\
\text { Elongate pebbles show well-defined } \\
\text { preferred orientation with their a- } \\
\text { axis aligned parallel to the bedding }\end{array}$ & $\begin{array}{l}\text { Subaerial depositional processes } \\
\text { resulting from stream floods in a } \\
\text { braided stream of an alluvial fan. } \\
\text { Well-developed gravel imbrications } \\
\text { indicate the presence of tractive } \\
\text { currents. Discontinuous red mudstones } \\
\text { suggest temporary exposures within } \\
\text { the braided channel system rather than } \\
\text { a well-developed flood plain. The } \\
\text { white carbonate horizons represent } \\
\text { caliche or calcrete, a layer of hard } \\
\text { paleosol encrusted with calcium } \\
\text { carbonate occurring in arid or semiarid } \\
\text { regions. The carbonates that } \\
\text { commonly form within soil profiles, } \\
\text { and therefore in very superficial } \\
\text { settings above the groundwater table, }\end{array}$ \\
\hline
\end{tabular}




\begin{tabular}{|c|c|c|}
\hline Facies & Description & $\begin{array}{l}\text { Suggested processes and } \\
\text { environment of deposition }\end{array}$ \\
\hline & $\begin{array}{l}\text { plane (Fig. 8A). Very coarse-grained } \\
\text { sandstone matrix. Few dm thick and } \\
\text { laterally discontinuous red } \\
\text { mudstones are locally embedded } \\
\text { within the conglomerates. } \\
\text { Occasional silt to mud sized, sub- } \\
\text { horizontal, repetitive white } \\
\text { carbonate layers (up to } 20 \mathrm{~cm} \text { thick } \\
\text { and couple tens of meters wide) } \\
\text { within the red mudstones and } \\
\text { conglomerates (Fig. 8B). Few } \\
\text { carbonate nodules. Irregular } \\
\text { carbonate layers of few m wide and } \\
\text { up to } 50 \text { cm thick are also observed } \\
\text { within the sandy matrix of the } \\
\text { conglomerates (Fig. } 8 \mathrm{C} \text { ) }\end{array}$ & $\begin{array}{l}\text { are interpreted as pedogenic calcretes } \\
\text { (Alonso-Zarza, 2003). The calcrete- } \\
\text { bearing paleosols within and/or on top } \\
\text { of fluvial deposits probably represent a } \\
\text { short period of tectonic quiescence } \\
\text { (Capuzzo et al., 1997). The } \\
\text { development of carbonates within the } \\
\text { matrix of conglomerates might be } \\
\text { related to shallow aquifer systems } \\
\text { where groundwater calcretes are } \\
\text { known to develop (Mann and Horwitz, } \\
\text { 1979) especially near the toes of large } \\
\text { alluvial fans (Mack et al., 2000) }\end{array}$ \\
\hline $\begin{array}{l}\text { F7: Clast- } \\
\text { supported } \\
\text { conglomerate }\end{array}$ & $\begin{array}{l}\text { Disorganized to poorly sorted, clast- } \\
\text { supported pebble-cobble } \\
\text { conglomerate (Fig. 8D). Very } \\
\text { prominent outcrops. Few very thick, } \\
\text { laterally extensive red to grey } \\
\text { tabular to lenticular beds or large- } \\
\text { scale trough cross beds with sharp, } \\
\text { locally scoured bases. Subrounded } \\
\text { to well rounded, } 3-5 \mathrm{~cm} \text { to } 8-10 \mathrm{~cm} \\
\text { polygenic clasts, with occasional } \\
\text { imbrications and some boulders } \\
\text { ( } 1 \text { m in diameter). Occasional } \\
\text { intergranular coarse-grained sand } \\
\text { fills in between pebbles (Fig. } 8 \mathrm{E} \text { and } \\
\text { F). Laterally very limited and up to } \\
10 \text { cm thick, coarse-grained } \\
\text { sandstone intercalations sporadically } \\
\text { occur, but are rapidly cut by the } \\
\text { succeeding conglomerate bed. Few } \\
\text { reworked mudstone fragments (up to } \\
1 \text { m in diameter) containing } \\
\text { abundant planktic foraminifera }\end{array}$ & $\begin{array}{l}\text { Sub-aerial to sub-aqueous processes } \\
\text { resulting from hyperconcentrated } \\
\text { flows, sheet-flows and/or stream } \\
\text { flows. An alluvial fan involving } \\
\text { braided stream (Nemec and Postma, } \\
\text { 1993) or sheet flood processes (Blair } \\
\text { and McPherson, 1994) may account } \\
\text { for this facies. A subaquatic } \\
\text { environment is also suggested by few } \\
\text { wave ripples observed in sandy } \\
\text { intercalations and by the presence of } \\
\text { reworked mudstone fragments with } \\
\text { abundant planktonic foraminifera. Its } \\
\text { association with the fossiliferous green } \\
\text { mudstone-calcareous sandstone (F1) } \\
\text { alternations suggests a proximal fan } \\
\text { delta environment }\end{array}$ \\
\hline
\end{tabular}


Table 2. : Diagnostic assemblages of planktic foraminifera of selected samples from the Çatallar Basin, (see Fig. 4a and b for location)

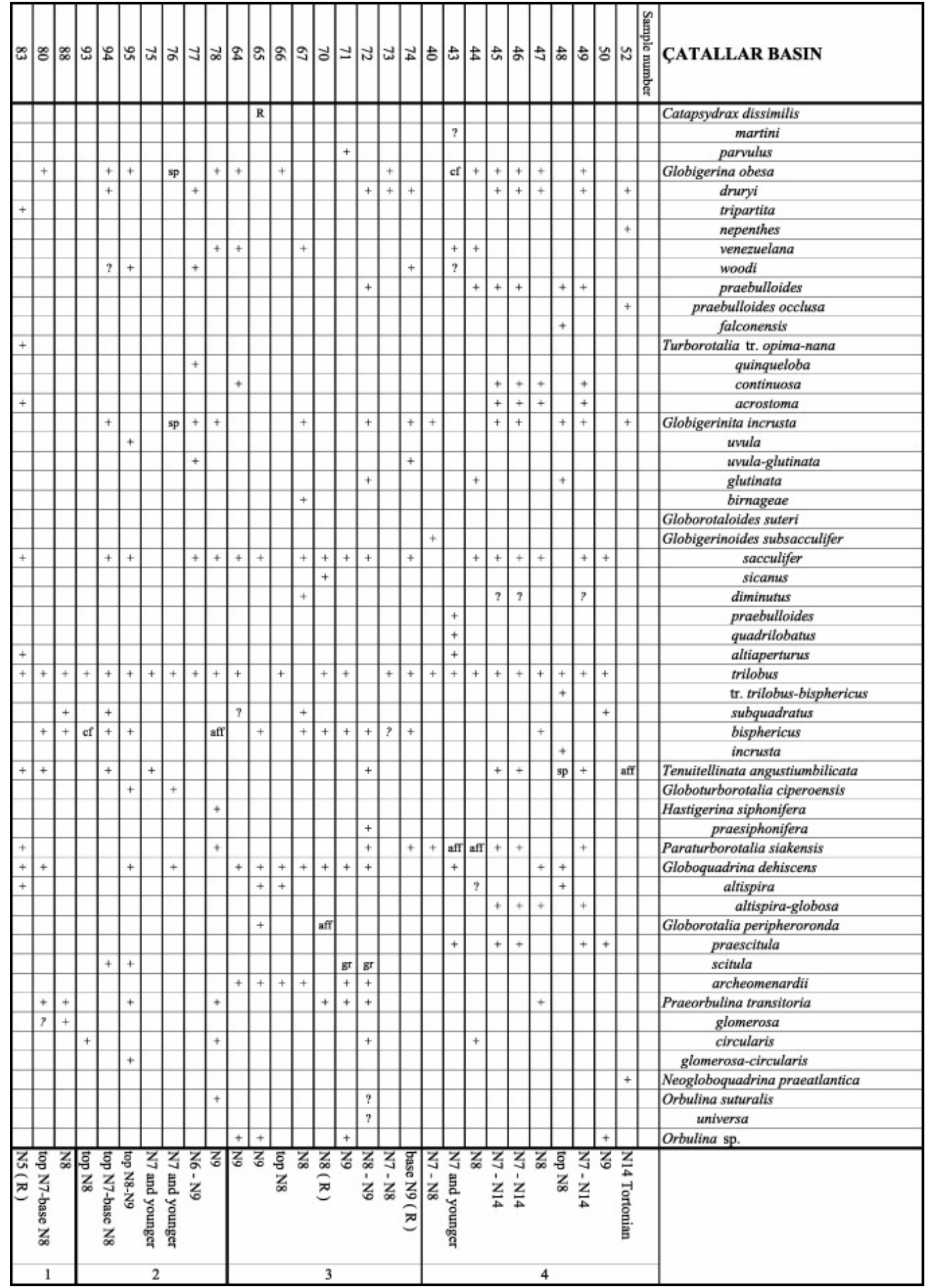


The complete planktic assemblages of the biozones identified from N7 to N14 are indicated. The chronostratigraphic interpretation is shown in Fig. 3 (gr: group; aff: affinis; cf: confere; sp: species; (R) reworked). Numbers below the table: 1 - Base of the Akçay formation near Akyaka and Çatallar before the arrival of the ophiolitic detritals. 2 - Hördübek and Günçalı Yaylas. 3 - Arif and Başkoz. 4 - Bağbeleni formation near Yalnız. For locations see Fig. 4a and $b$. 